\title{
THE EFFECTS OF THE CARBONIC ANHYDRASE INHIBITOR “6063" ON ELECTROLYTES AND ACID-BASE BALANCE IN TWO NORMAL SUBJECTS AND TWO PATIENTS WITH RESPIRATORY ACIDOSIS ${ }^{1}$
}

\author{
By JUDITH NADELL with THE technical assistance of HELEN KALINSKY
}

\author{
(From the Research Service, First [Columbia] Division, Goldwater Memorial Hospital, De- \\ partment of Hospitals, New York City, and the Department of Medicine, College of \\ Physicians and Surgeons, Columbia University, New York City, N. Y.)
}

(Submitted for publication January 13, 1953; accepted March 18, 1953)

\section{INTRODUCTION}

The effects of oral administration of sulfanilamide in man on acid-base metabolism have been reported previously $(1,2)$. Sulfanilamide produces a transient increase in urine $\mathrm{pH}, \mathrm{CO}_{2}$ content, sodium and potassium and a transient decrease in urinary ammonia. These urinary changes are associated with a fall in the serum $\mathrm{CO}_{2}$ content and a rise in serum chloride. The inhibition of the enzyme carbonic anhydrase by sulfanilamide was described by Mann and Keilin (3). It is believed that the effects of sulfanilamide on electrolyte and acid-base balance are due to the inhibition of this enzyme in the cells of the renal tubules (4). In 1949, Schwartz (5) reported the diuretic effect of sulfanilamide in three patients with congestive heart failure. However, the toxicity of this drug appeared to limit its possible usefulness as a diuretic agent.

In 1950, Roblin and Clapp (6) described the preparation and properties of a series of heterocyclic sulfonamides. Their activity as potent inhibitors of the enzyme carbonic anhydrase in vitro was further investigated and amplified by Miller, Dessert and Roblin (7). The present study concerns some of the effects of one of these compounds “6063" (Diamox ${ }^{\mathrm{Bx}}{ }^{2}$ ) (2 acetylamino-1,-3,4 thiadiazole-5-sulfonamide) on electrolyte and acidbase metabolism.

\section{METHODS}

Two male patients (W. B., age 32 and M. W., age 30 ), with neurological disease (muscular dystrophy and cere-

\footnotetext{
1 Supported in part by the Chemotherapy Division, Stamford Research Laboratories, American Cyanamid Company, The National Heart Institute, and the Albert and Mary Lasker Foundation.

2 Provided by Lederle Laboratories Division, American Cyanamid Co., New York City.
}

bral palsy) but without evidence of cardiac, renal or pulmonary disease were studied. In addition, two male patients (W. M., age 52 and S. D., age 64) with long-standing pulmonary emphysema and well documented respiratory acidosis were also studied. The latter patients had no evidence of renal functional impairment; both had electrocardiographic evidence of cor pulmonale and had exhibited a mild degree of right-sided congestive failure in the past for which they had been digitalized. Neither had evidence of cardiac failure at the time of these studies.

The subjects under invéstigation were placed on a constant diet containing $5 \mathrm{mEq}$. of sodium per day and received, in addition, $50 \mathrm{mEq}$. of sodium per day in the form of $\mathrm{NaCl}$ capsules. There was a constant daily intake of protein, fat and carbohydrate. Water was permitted ad lib. Daily 24-hour urine specimens were collected under mineral oil with the use of a special funnellike urinal designed to minimize the loss of gases. A small amount of thymol was used as a preservative and the urine collecting bottles were kept on ice at the patients' bedsides. Determinations were made daily of urine volume, specific gravity, $\mathrm{pH}, \mathrm{CO}_{2}$ (8), ammonia (9), chloride (10), sodium, potassium and phosphate (11). The $\mathrm{CO}_{2}$ content of urine kept under the described conditions was found to be approximately 1 to $2 \mathrm{mM}$ per L. lower than that of freshly voided acid urine. The $\mathrm{CO}_{2}$ loss from alkaline urine was found to be negligible. Determinations of blood $\mathrm{pH}$, and plasma $\mathrm{CO}_{2}$ content (8), chloride $(10)$, sodium and potassium were performed at intervals as indicated in Figures 2, 4, 6, and 8. Urine and blood $\mathrm{pH}$ were determined with the Beckman $\mathrm{pH}$ meter Model G. The $\mathrm{pH}$ determinations were performed at room temperature (approximately $25^{\circ} \mathrm{C}$.). The blood $\mathrm{pH}$ values were corrected to $37^{\circ} \mathrm{C}$. by subtracting 0.014 pH units per degree difference in temperature. The urine pH values were not corrected for temperature. Urine and blood sodium and potassium were determined on an internal standard flame photometer (12). The $\mathrm{pCO}_{2}$ was calculated from the arterial $\mathrm{pH}$ and $\mathrm{CO}_{2}$ content using the Henderson-Hasselbalch equation and $\mathrm{a} \mathrm{pK}$ value of 6.1 for $\mathrm{H}_{2} \mathrm{CO}_{2}$. All blood samples were obtained from the brachial artery and were collected under mineral oil. During the experimental periods on "6063" blood samples were collected approximately two hours after the administration of the drug. 
After a foreperiod of 12 to 15 days the patients were started on oral "6063"; initially 8 to $10 \mathrm{mg}$. per kg. body weight per day were given in four divided doses at sixhour intervals. In some cases the dose was later increased up to $18 \mathrm{mg}$. per $\mathrm{kg}$. body weight per day.

\section{RESULTS}

Figures 1 to 8 show the changes in the blood and urine constituents for each patient. The table gives a summary of the results obtained in the urine studies.

Acute changes. During the first two days of administration of " 6063 " there was an increase in the urine $\mathrm{pH}$ and a 10 to 20 fold increase in the urine $\mathrm{CO}_{2}$ content. There was also an increased urinary excretion of sodium and potassium (one to four fold) and a slight increase in urinary phosphate.

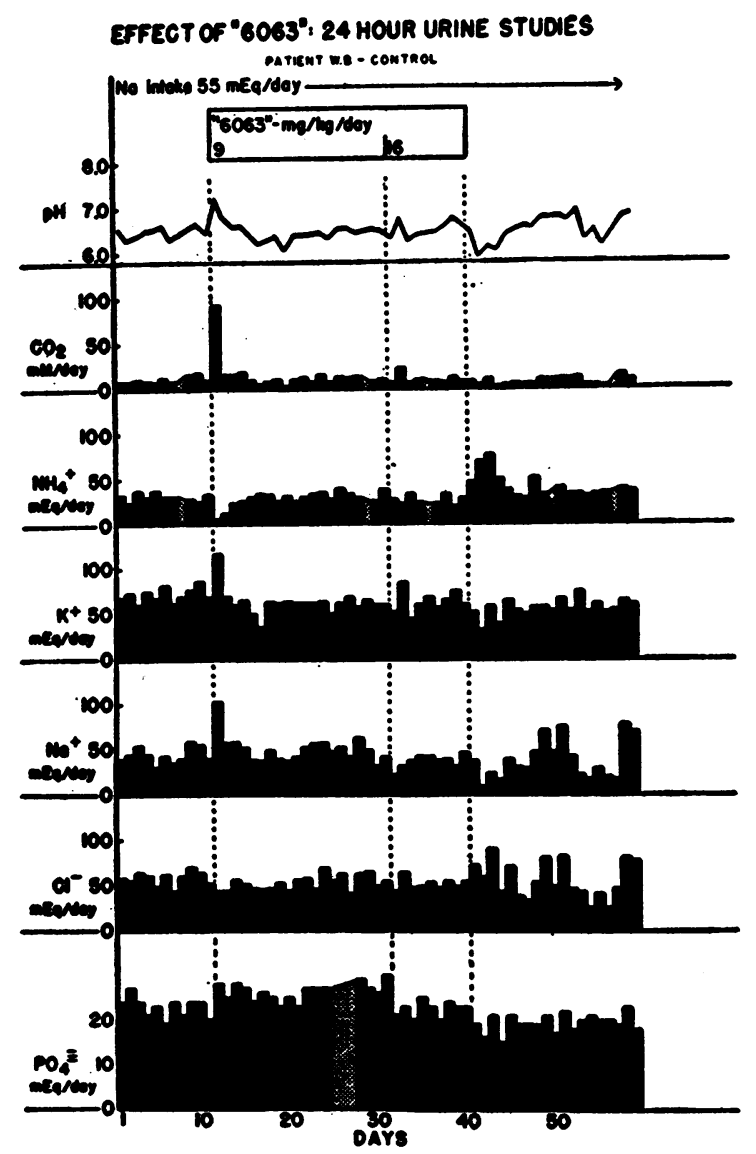

Fig. 1. Daily 24-hour Urine Constituents of Control Patient W. B. (Muscular Dystrophy) during Study Period

The stippled areas indicate days when determination was omitted for technical reasons.

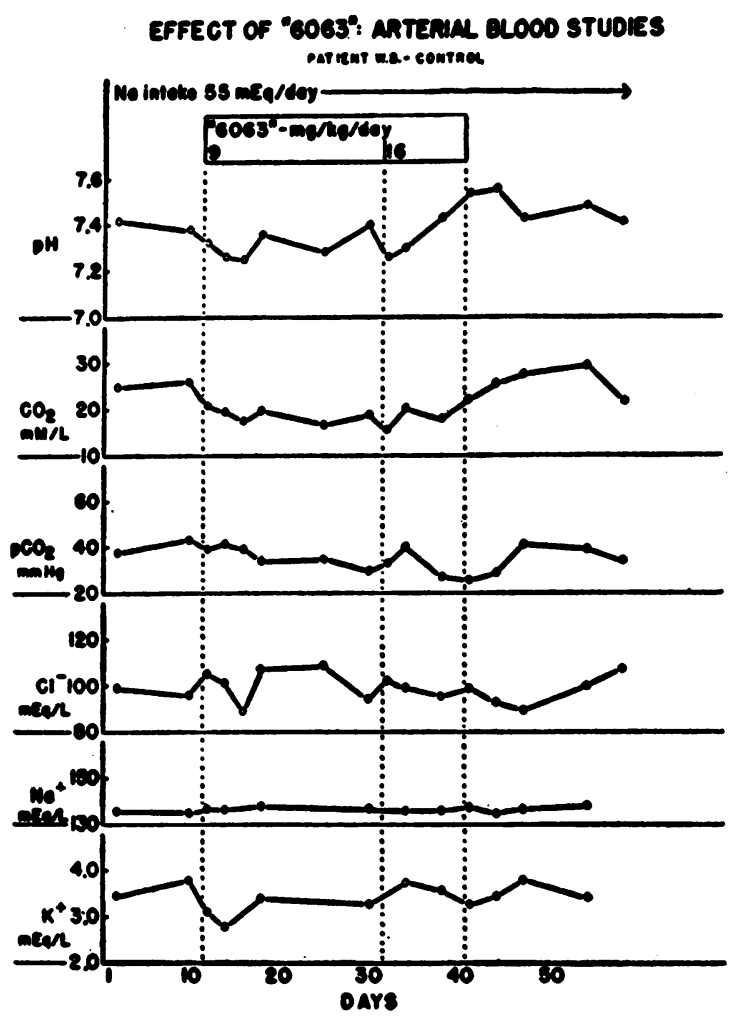

Fig. 2. Arterial Blood Studies of Patient W. B.

Urinary ammonia decreased about 50 per cent. There was no significant change in urine chloride. There was no significant change in urine volume. Consistent results were seen in all four patients.

One day after the drug was started there was a fall in arterial $\mathrm{pH}(0.1$ to $0.2 \mathrm{pH}$ units ) associated with a fall in the plasma $\mathrm{CO}_{2}$ content of 5 to 10 $\mathrm{mEq}$. per $\mathrm{L}$. In three of the four patients there was an associated rise in the plasma chloride concentration. During the first week of the drug therapy there was a fall in the plasma potassium concentration. There were no clinical symptoms of hypokalemia. There was no significant change in the plasma sodium concentration.

Changes with prolonged administration of "6063". After a maximum of three days the urine $\mathrm{pH}$ and electrolyte excretion returned to control values and continued unchanged for the remaining 25 to 55 days of drug administration. When the dosage was increased up to a maximum of $18 \mathrm{mg}$. per kg. per day there was no further change in the urinary constituents. These dosages are comparatively small; larger doses might have yielded different results. 


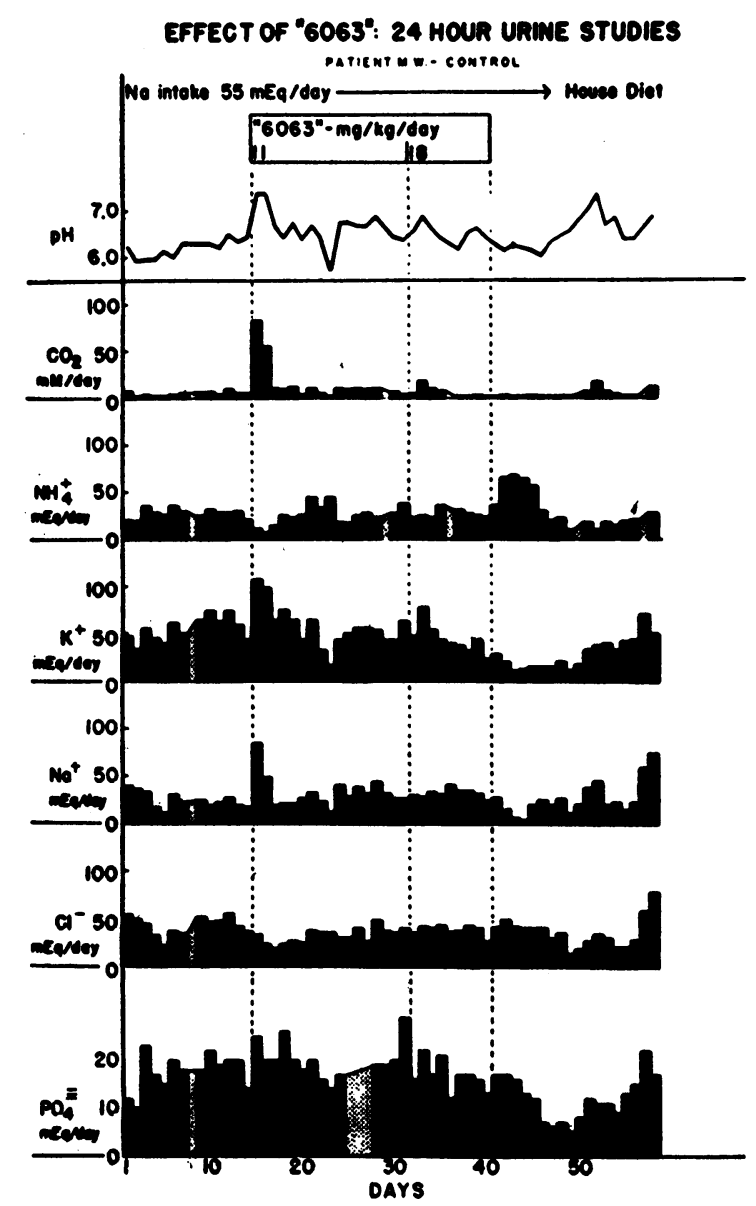

Fig. 3. Daily 24-hour Urine Constituents of Control Patient M. W. (Cerebral Palsy) during Study PERIODS

During the entire period of administration of " 6063 " the arterial $\mathrm{CO}_{2}$ content was depressed 5 to $10 \mathrm{mEq}$. per $\mathrm{L}$. below the control values in both groups. However, the arterial $\mathrm{pH}$ tended to return to control values, and in both patients with respiratory acidosis, where the $\mathrm{pH}$ had previously been low, it rose to normal several weeks after therapy was started. This was due to a fall in the arterial $\mathrm{pCO}_{2}$. In the patients with respiratory acidosis the plasma chloride rose, in one case to normal. After the initial period of depression, the plasma potassium tended to return to control values. There was no change in the plasma sodium concentration.

Changes on discontinuation of "6063". For one to five days after the discontinuation of " 6063 ," there was decreased urinary excretion of sodium with no significant change in urine chloride ex- cretion. In one of the three patients studied in this period (M. W.), there was also a significant decrease in potassium excretion. For four to six days after cessation of " 6063 " therapy, there was increased urinary excretion of ammonia in all cases.

After the drug was discontinued the arterial $\mathrm{CO}_{2}$ content in the control patients returned to normal in four to five days; the arterial $\mathrm{pH}$ rose to abnormally high values ( 7.55 to 7.56 ) in four to seven days. Three to four days later, the arterial $\mathrm{pH}$ had returned to normal. In the patients with respiratory acidosis the arterial $\mathrm{CO}_{2}$ content rose to previous values in three to five days; the arterial $\mathrm{pH}$ fell to previous control values in five to seven days.

Clinical changes. The two control subjects were asymptomatic during the entire period of study. One patient (W. M.) (Figures 7 and 8), who had previously been comatose because of respiratory acidosis and who had required the daily use of a respirator, was maintained in an alert state outside the respirator for two separate periods while receiving "6063". Initially, the patient received

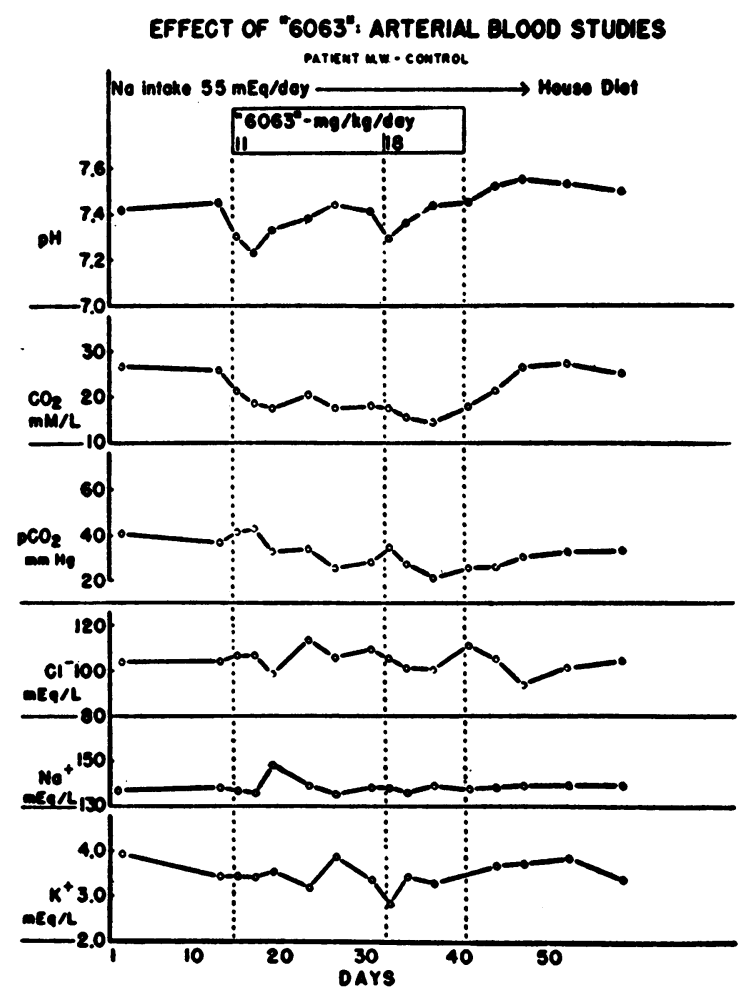

Fig. 4. Arterial Blood Studies of Patient M. W. 
EFFECT OF "6063": 24 HOUR URINE STUDIES patient so-atspinatonr acioosis

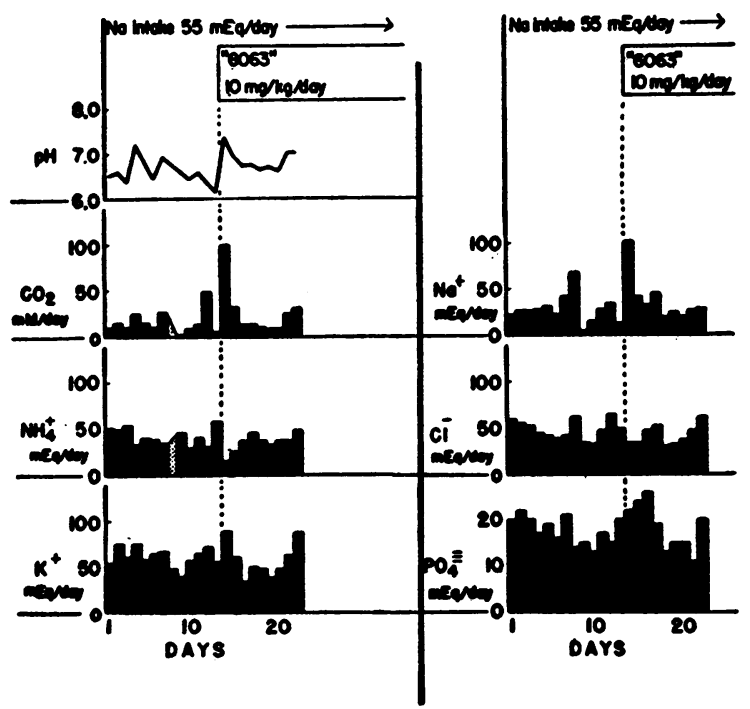

Fig. 5. DaIly 24-hour Urine Constituents of PaTIENT S. D. (RESPIRATORY AcIDOSIS)

The urine studies were discontinued prematurely because of the development of a urinary tract infection.

"6063" ( $8 \mathrm{mg}$. per kg. body weight per day) for three weeks and remained alert. One week after discontinuation of " 6063 ," the patient developed more marked respiratory acidosis with associated

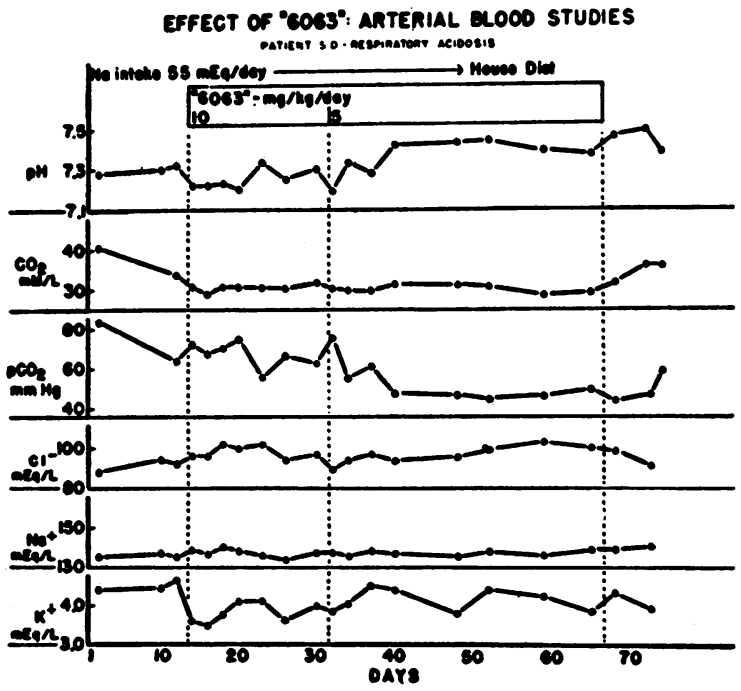

Fig. 6. Arterial Blood Studies of Patient S. D.

Two weeks after the initiation of "6063" (10 mg. per kg. per day), the patient (S. D.) became drowsy and confused. These symptoms disappeared promptly when the dosage was lowered to $5 \mathrm{mg}$. per $\mathrm{kg}$. per day. drowsiness and neuromuscular irritability. Reinstitution of "6063" therapy (10 mg. per kg. body weight per day) was followed by symptomatic and chemical improvement and, at the time of this writing, (November, 1952), with continued use of the drug, the patient has remained alert without use of

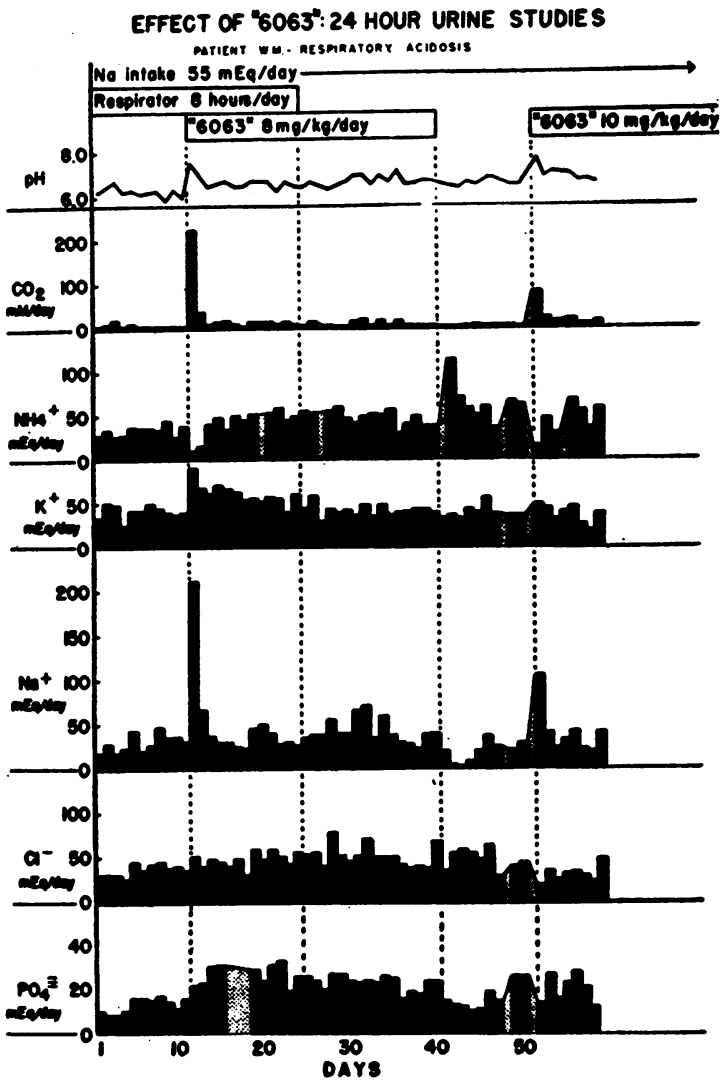

Fig. 7. Daily 24-hour Urine Constituents of PaTIENT W. M. (RESPIRATORY AcIDOSIS)

Patient W. M. had been in coma with respiratory acidosis on three occasions in the two months preceding this study. These episodes of coma were not related to changes in oxygen therapy. The coma had cleared on all three occasions following the use of a Drinker respirator, during which time there was a fall in the blood $\mathrm{CO}_{2}$ content. These studies were started when the patient was still being maintained in a respirator eight hours each day. Two weeks after the initiation of "6063" therapy the patient was removed from the respirator, the " 6063 " being continued for three additional weeks. The patient remained alert. However, one week after discontinuation of "6063" the patient developed marked drowsiness and neuromuscular irritability and asked to be returned to the respirator. This was associated with a marked rise in arterial blood $\mathrm{CO}_{2}$ content and a fall in $\mathrm{pH}$. Instead of respirator therapy the patient was given "6063" and his symptoms disappeared promptly. 


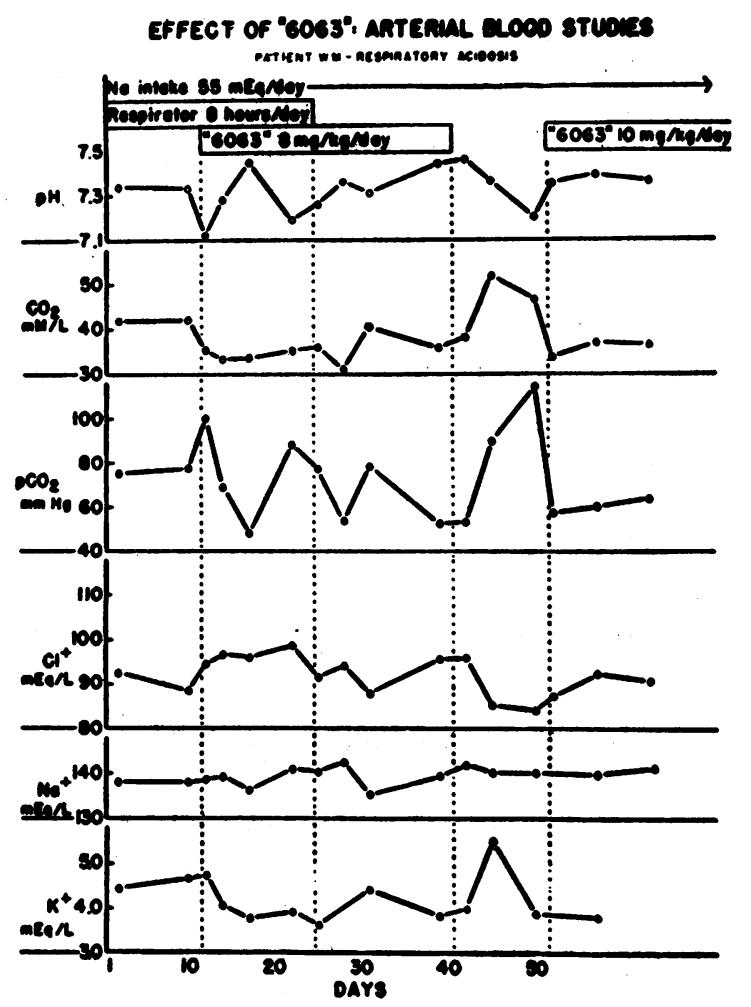

Fig. 8. Daily Arterial Blood Studres of Patient W. M. (Respiratory Acrdosis)

See legend to Figure 7.

the respirator for three months. No late side effects have been observed.

The other patient (S. D.), with respiratory acidosis but without antecedent alteration of consciousness, developed marked drowsiness 14 days after the initiation of therapy. This was not correlated with changes in the arterial $\mathrm{pH}$ or $\mathrm{CO}_{2}$. These symptoms disappeared promptly when the dose was decreased from 10 to $5 \mathrm{mg}$. per $\mathrm{kg}$. per day. No other toxic manifestations or clinical changes were noted.

Four additional patients with severe pulmonary emphysema and respiratory acidosis have received oral " 6063 " in more limited studies. In all four there was an initial fall in the plasma $\mathrm{CO}_{2}$ content of 5 to $10 \mathrm{mEq}$. per $\mathrm{L}$. In three patients the $\mathrm{CO}_{2}$ content remained depressed during the entire two to four week period of " 6063 " administration. These three patients were alert prior to and during this study. The fourth patient had had drowsiness due to respiratory acidosis. His mental status cleared and his plasma $\mathrm{CO}_{2}$ content decreased coincident with initiation of "6063" therapy. However, in this latter patient the plasma $\mathrm{CO}_{2}$ content rose to pre-treatment levels despite continued administration of " 6063 " and the patient again developed drowsiness which cleared only after five days of Drinker respirator therapy.

\section{DISCUSSION}

In normal renal function carbonic acid $\left(\mathrm{H}_{2} \mathrm{CO}_{3}\right)$ is believed to be the main source of hydrogen ion necessary for the acidification of the urine, the formation of ammonium ion $\left(\mathrm{NH}_{4}^{+}\right)$from ammonia $\left(\mathrm{NH}_{3}\right)$, and the distal tubular reabsorption of sodium. The reaction $\mathrm{CO}_{2}+\mathrm{H}_{2} \mathrm{O} \rightleftharpoons \mathrm{H}_{2} \mathrm{CO}_{3}$ $\left(\rightleftharpoons \mathrm{H}^{+}+\mathrm{HCO}_{3}^{-}\right)$is catalyzed by the enzyme carbonic anhydrase which is found in the renal cortex in high concentration (13). Most of the immediate effects of the administration of an inhibitor of carbonic anhydrase (such as sulfanilamide or " 6063 ") on acid-base equilibrium can be explained by interference with the renal mechanisms in which this enzyme is presumably involved. Inhibition of carbonic anhydrase in the kidney leads to:

1. Decreased acidity of urine due to decreased availability of the hydrogen ion from carbonic acid.

2. Increased urinary excretion of sodium due to disruption of the tubular exchange mechanism $(14,15)$ in which hydrogen ion is normally excreted by the tubule cell and sodium reabsorbed.

3. Increased urinary excretion of potassium due to increased tubular secretion of potassium. Inhibition of renal carbonic anhydrase is thought to produce a relative alkalosis in the renal tubule cells because of reduction of available hydrogen ion $(15,16)$. The normally occurring "competition" between hydrogen and potassium in the ion exchange mechanism of sodium reabsorption is disrupted $(17,18)$. Exchange of potassium for sodium rather than hydrogen for sodium is favored and potassium secretion is increased (15).

4. Decreased ammonium ion $\left(\mathrm{NH}_{4}^{+}\right)$excretion due to limited availability of hydrogen ion for combination with ammonia $\left(\mathrm{NH}_{3}\right)$; the decreased ammonium ion formation also leads to enhanced urinary excretion of sodium (18). 
EFFECT OF “6063” IN RESPIRATORY ACIDOSIS

TABLE I

Effect of "6063" on urine constituents of four subjects

Constant diet containing $55 \mathrm{mEq}$. sodium per day*

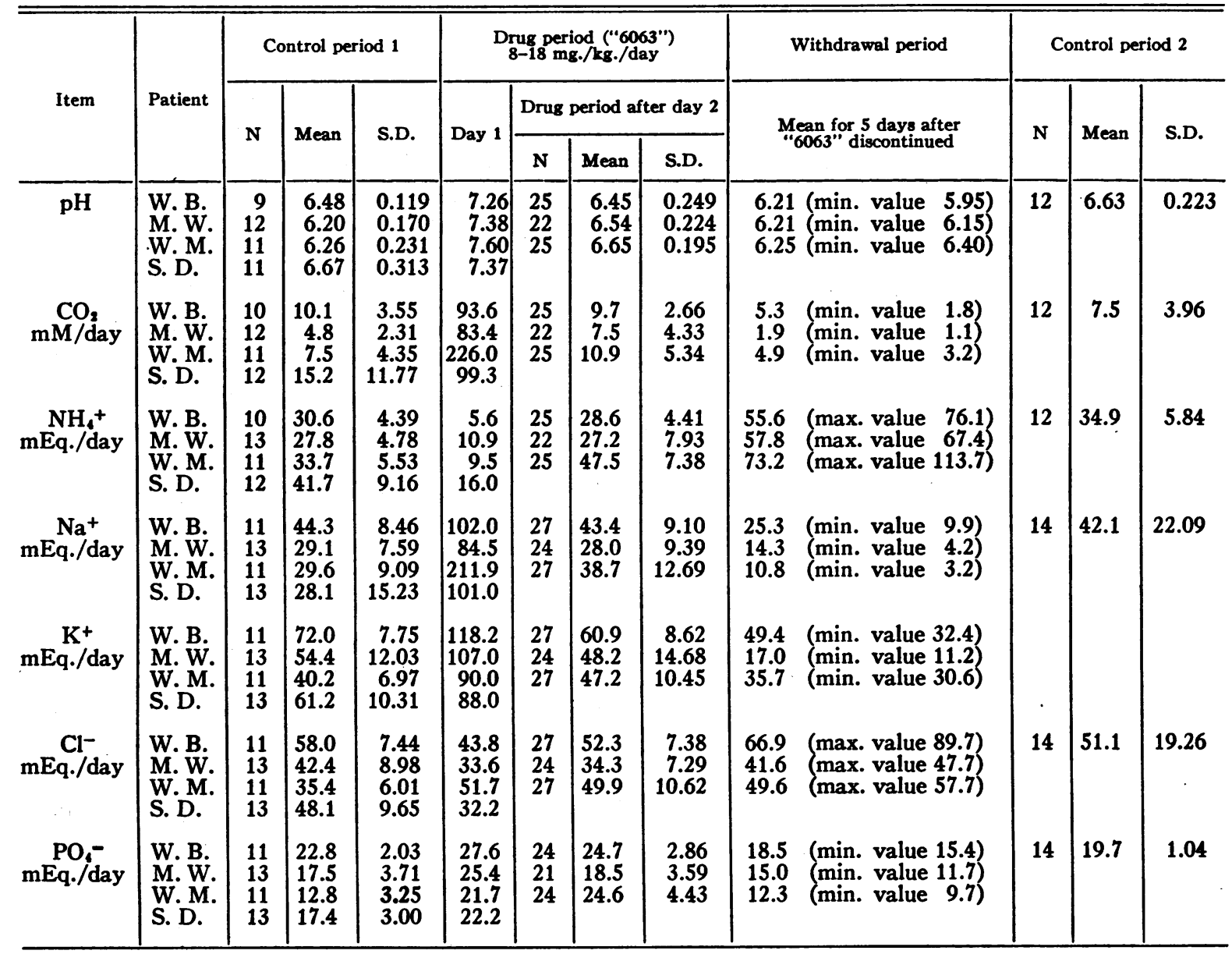

* N-Number of determinations.

S.D.-Standard deviation.

5. Increased total $\mathrm{CO}_{2}$ content of urine, due mainly to increased excretion of bicarbonate. Normally, hydrogen ion secreted by the renal tubule cells reacts with the bicarbonate in the tubular urine; the $\mathrm{CO}_{2}$ so evolved diffuses into the blood. When hydrogen ion secretion is diminished by carbonic anhydrase inhibition this reaction does not take place and bicarbonate excretion is thereby increased $(18,19)$.

The acute loss of large quantities of sodium and potassium bicarbonate via the urine is associated with a fall in plasma bicarbonate and blood $\mathrm{pH}$. A significant fall in the plasma potassium concentration occurred in three of the four patients studied. No change in plasma sodium occurred.
Increased urinary excretion of phosphate occurred after the administration of "6063." Increased urinary phosphate occurs also in acidosis from other causes (20). The mechanism is not known.

With prolonged administration of " 6063 " the changes in urinary excretion of electrolytes lasted only one to two days. Thereafter, urine electrolytes were essentially the same as during the control period. The nature of this apparent urinary compensation is not known. There are several possible explanations. There may be renal mechanisms other than that involving carbonic anhydrase which can make hydrogen ion available; increased amounts of carbonic anhydrase may permit the 
normal reaction to proceed in spite of the presence of the inhibitor. All of the reactions may not require an enzymatic catalyst.

With the exception of the $\mathrm{CO}_{2}$ content, the changes in arterial blood electrolytes tended to return to control values after one to two weeks of continued drug therapy. Although the arterial $\mathrm{pH}$ tended to return to normal, the plasma $\mathrm{CO}_{2}$ content remained depressed ( 5 to $10 \mathrm{mEq}$. per L.) during the entire period of administration of " 6063 " in both control subjects and in five of the six patients with respiratory acidosis studied. This was due to a fall in the arterial $\mathrm{pCO}_{2}$. As this is completely under pulmonary control, the fall in arterial $\mathrm{pCO}_{2}$ associated with a rise in arterial $\mathrm{pH}$ must be attributed to respiratory compensation for the metabolic acidosis, i.e., hyperventilation. The patients with respiratory acidosis and control $\mathrm{CO}_{2}$ tensions of about $80 \mathrm{~mm}$. $\mathrm{Hg}$ initially must have had either a) pulmonary ventilation impaired to the point that effective diffusion of $\mathrm{CO}_{2}$ from the blood was impossible despite maximal ventilatory effort, or b) insensitivity of the respirator center and/or chemoreceptors to the stimulus of a high arterial $\mathrm{pCO}_{2}$. It is interesting to note that the pulmonary dissipation of $\mathrm{CO}_{2}$ is apparently more effective following the administration of "6063". The mechanism is obscure.

Because carbonic anhydrase is thought to be important in the secretion of acid in the gastric juice (21), gastric analyses were performed before and during " 6063 " therapy in the control patients. There was no significant change in gastric secretion of free or combined acid or of the electrolytes of the gastric juice before or after histamine stimulation one day or seven days after the initiation of " 6063 " in the doses used.

"Rebound phenomena" after cessation of " 6063 " are prominent. They last for more than one week and consist of decreased urinary excretion of sodium and in one case of potassium, increased ammonia and decreased phosphate excretion. There was a rise of blood $\mathrm{pH}$ to above control levels, and a return of blood $\mathrm{CO}_{2}$ content to control levels only after about one week. The retention of sodium after withdrawal of " 6063 " indicates that the initial large loss of sodium, on administration of the drug, may not be made up while " 6063 " is administered even though urinary output of sodium is the same as during the control pe- riod. One patient (M. W.) was given $170 \mathrm{mEq}$. of sodium per day as $\mathrm{NaCl}$ in capsule form, in addition to a diet containing approximately 50 $\mathrm{mEq}$. of sodium per day. After a control period of one week "6063" was given as previously described. The effects of the drug were the same as with the smaller sodium intake except for the baseline levels of the control period. Withdrawal of " 6063 " was followed by a period of diminished sodium excretion from control levels of about 150 $\mathrm{mEq}$. per day to about $20 \mathrm{mEq}$. per day for several days. Thus, "rebound phenomena" were present in spite of a relatively large continuous intake of sodium. The explanation for these "rebound phenomena" is obscure. It is possible that the same mechanism that caused urinary excretion of electrolytes to return to control levels during prolonged administration of " 6063 " continued to operate for some time after the drug was discontinued.

\section{SUMMARY}

1. The effects of administration of the carbonic anhydrase inhibitor "6063" on electrolyte and acid-base metabolism have been studied in two normal subjects and two patients with pulmonary emphysema and respiratory acidosis. The electrolyte changes in both groups were essentially the same.

2. Administration of " 6063 " causes transient increased urinary $\mathrm{pH}$, increased urinary $\mathrm{CO}_{2}$, sodium, potassium and phosphate and a fall in urinary ammonia. Associated with this there is a fall in arterial $\mathrm{pH}$ and $\mathrm{CO}_{2}$ content. There is a transient decrease in the plasma potassium concentration. After two to three days the daily urinary excretion of electrolytes returns to the levels of the control period, but the plasma $\mathrm{CO}_{2}$ content remains depressed during the entire period of drug administration and the arterial $\mathrm{pH}$ only gradually rises to the control levels. Upon cessation of "6063" therapy, there is decreased urinary excretion of sodium, increased urinary ammonia and a rise of blood $\mathrm{pH}$ to above control values for three to seven days.

\section{REFERENCES}

1. Hartmann, A. F., Perley, A. M., and Barnett, H. L., A study of some of the physiological effects of sulfanilamide. I. Changes in the acid-base balance. J. Clin. Invest., 1938, 17, 465. 
2. Beckman, W. W., Rossmeisl, E. C., Pettengill, R. B., and Bauer, W., A study of the effects of sulfanilamide on acid-base metabolism. J. Clin. Invest., $1940,19,635$.

3. Mann, T., and Keilin, D., Sulphanilamide as a specific inhibitor of carbonic anhydrase. Nature, London, 1940, 146, 164.

4. Pitts, R. F., and Alexander, R. S., The nature of the renal tubular mechanism for acidifying the urine. Am. J. Physiol., 1945, 144, 239.

5. Schwartz, W. B., The effect of sulfanilamide on salt and water excretion in congestive heart failure. New England J. Med., 1949, 240, 173.

6. Roblin, R. O., Jr., and Clapp, J. W., The preparation of heterocyclic sulfonamides. J. Am. Chem. Soc., 1950, 72, 4890.

7. Miller, W .H., Dessert, A. M., and Roblin, R. O., Jr., Heterocyclic sulfonamides as carbonic anhydrase inhibitors. J. Am. Chem. Soc., 1950, 72, 4893.

8. Peters, J. P., and Van Slyke, D. D., Quantitative Clinical Chemistry, Vol. II. Methods. Williams \& Wilkins Co., Baltimore, 1932, p. 283.

9. Van Slyke, D. D., and Cullen, G. E., The determination of urea by the urease method. J. Biol. Chem., 1916, 24, 117.

10. Van Slyke, D. D., The determination of chlorides in blood and tissues. J. Biol. Chem., 1923, 58, 523.

11. Fiske, C. H., and Subbarow, Y., Colorimetric determination of phosphorus. J. Biol. Chem., 1925, $66,375$.
12. Berry, J. W., Chappell, D. G., and Barnes, R. B., Improved method of flame photometry. Indust. \& Engin. Chem. (Anal. Ed.), 1946, 18, 19.

13. Davenport, H. W., and Wilhelmi, A. E., Renal carbonic anhydrase. Proc. Soc. Exper. Biol. \& Med., 1941, 48, 53.

14. Pitts, R. F., Lotspeich, W. D., Schiess, W. A., and Ayer, J. L., The renal regulation of acid-base balance in man. I. The nature of the mechanism for acidifying urine. J. Clin. Invest., 1948, 27, 48.

15. Berliner, R. W., Kennedy, T. J., Jr., and Orloff, J., Relationship between acidification of the urine and potassium metabolism. Effect of carbonic anhydrase inhibition on potassium excretion. Am. J. Med., 1951, 11, 274.

16. Mudge, G. H., Ames, A., III, Foulks, J., and Gilman, A., Effect of drugs on renal secretion of potassium in the dog. Am. J. Physiol., 1950, 161, 151.

17. Berliner, R. W., Kennedy, T. J., Jr., and Hilton, J. G., Renal mechanisms for excretion of potassium. Am. J. Physiol., 1950, 162, 348.

18. Pitts, R. F., Acid-base regulation by the kidneys. Am. J. Med., 1950, 9, 356.

19. Pitts, R. F., and Lotspeich, W. D., Bicarbonate and the renal regulation of acid base balance. Am. J. Physiol., 1946, 147, 138.

20. Smith, H. W., The Kidney. Oxford University Press, New York, 1950, p. 117.

21. Davenport, H. W., Carbonic anhydrase in tissues other than blood. Physiol. Rev., 1946, 26, 560. 